Piotr Opaliński

Akademia Sztuk Pięknych im. Jana Matejki w Krakowie

iD ORCID ID: 0000-0002-4171-8217
OBLICZA WOJNY

TOM 5 - MIASTO I WOJNA

ŁÓDŹ2021 •ISBN978-83-8220-699-9 •s.129-154 https://doi.org/10.18778/8220-699-9.08

\title{
NOYAU KRAKOWSKIEJ TWIERDZY W DRUGIEJ POŁOWIE XIX WIEKU
}

\begin{abstract}
Streszczenie. W 1857 r. władze austriackie rozpoczęły w krakowskiej twierdzy realizację wewnętrznej linii obrony w postaci tak zwanego Noyau. Kraków jako niezwykle ważny punkt strategiczny na mapie monarchii Habsburgów wymagał pilnego ufortyfikowania. Prace poprzedziły studia terenowe oraz rozważania nad kilkoma wariantami planowanych umocnień. W trakcie realizacji pojawiły się przeszkody, które spowodowały zakończenie inwestycji dopiero po 9 latach. Budowa Noyau zapisała się trwale w dziejach miasta, wpływając na jego urbanistykę oraz rozwój przestrzenny. Mimo niwelacji większości umocnień nadal widzimy ślad ich obecności w postaci układu arterii komunikacyjnych otaczających dzisiejsze śródmieście Krakowa.
\end{abstract}

Słowa kluczowe: fortyfikacje, twierdza Kraków, Noyau, obrona miasta, Cornelius von Wurmb

\section{Koncepcje umocnień obozu warownego}

W latach 1848-1849 przez Europę przetoczyła się fala rewolucyjnych wystąpień. Cesarstwo Austrii wygrało wojnę w północnych Włoszech oraz wspólnie z Rosją stłumiło dążenia niepodległościowe na Węgrzech. Zamieszki nie ominęły również Krakowa, ostatniego fragmentu Rzeczypospolitej włączonego zaledwie dwa lata wcześniej w skład monarchii Habsburgów. Wiadomości z Francji oraz zajścia na ulicach Wiednia wywołały wrzenie w przeżywającym stagnację gospodarczą mieście. Krótkie walki zakończone zostały 26 kwietnia 1848 r. dwugodzinnym bombardowaniem miasta przez artylerię ustawioną na stokach Zamku Wawelskiego. W sumie zginęło 32 cywilów oraz 8 żołnierzy austriackich ${ }^{1}$. Równie bezwzględnie spacyfikowano Lwów.

${ }^{1}$ J. Gollenhofer, Rewolucya krakowska 1848 roku, Kraków 1908, s. 92-93. 
Kryzys wywołany Wiosną Ludów postawił monarchię przed problemem zbyt słabego zabezpieczenia kraju zarówno wewnątrz, jak i na peryferiach. Rzecz wymagała pilnego rozpatrzenia. W listopadzie 1849 r. cesarz Franciszek Józef I powołał Centralną Komisję Fortyfikacyjną pod przewodnictwem feldmarszałka Heinricha von Hessa ${ }^{2}$. W efekcie obrad członkowie komisji postanowili zrealizować szereg umocnionych punktów w najbardziej zagrożonych obszarach. Na południowym zachodzie zdecydowano o modernizacji Czworoboku Fortecznego Werony, Peschiery, Mantui i Legnago oraz budowie blokhauzów zaporowych na przełęczach gór Tyrolu. Uznano za konieczne ufortyfikowanie wybrzeża Weneckiego, Dalmackiego oraz półwyspu Istria, w celu ochrony portów wojennych na Adriatyku. Na Węgrzech w dolnym biegu Dunaju wzmacniano Komarno, Budapeszt i Peterwardein. Północ miała osłaniać rozbudowana morawska twierdza w Ołomuńcu. Północny wschód, czyli ziemie inkorporowane w wyniku rozbiorów Rzeczypospolitej, miały zabezpieczyć obozy warowne, których budowę rozważano w Krakowie, Przemyślu, Tarnowie, we Lwowie i w Zaleszczykach ${ }^{3}$.

Spośród pięciu galicyjskich lokalizacji austriacka Komisja Hessa wybrała Kraków jako miejsce przeznaczone w pierwszej kolejności do ufortyfikowania. Przewidziana w tym miejscu twierdza miała za zadanie zablokować najkrótszy kierunek operacyjny prowadzący z Imperium Rosyjskiego przez Bramę Morawską do stolicy Cesarstwa Austriackiego, Wiednia. Jako baza zaopatrzeniowa Kraków mógł wspierać armię polową manewrującą w obszarach Galicji Zachodniej oraz na przedpolach Karpat. Nowoczesna twierdza miała być realizowana pod nadzorem Naczelnego Inspektora Inżynierii generała Bernharda von Cabogi, zgodnie z regułami stosowanego w krajach Związku Niemieckiego od lat dwudziestych XIX w. systemu poligonalnego ${ }^{4}$.

\footnotetext{
2 F. FORSTNER, Twierdza Przemyśl, Warszawa 2000, s. 41.

3 J. BogdanOwski, Fortyfikacje austriackie na terenie Galicji w latach 1850-1914, Kraków 1993, s. 10 .

${ }^{4}$ Po wojnach napoleońskich na terytorium Związku Niemieckiego, któremu przewodniczyła Austria, wprowadzone zostały nowe zasady projektowania fortyfikacji w systemie poligonalnym. Nowa koncepcja rozwinięta została w Prusach przez Gustava von Raucha (1774-1841), Ernsta von Astera (1778-1855) i Johanna von Bresego (1787-1878), zainspirowanych teoriami francuskiego inżyniera wojskowego Marca Montalemberta (1714-1800). Wybitnym propagatorem nowego systemu w Austrii był generał Franz von Scholl (1772-1838), projektant umocnień twierdz w Moguncji, Ulm, Wenecji, Mantui oraz Veronie.
} 
Nowy system w odróżnieniu od starszego bastionowego pozwalał na swobodne prowadzenie linii obwodu obronnego w dowolnie ukształtowanym terenie. Wieloboczny linearny narys był prostszy w realizacji, przy czym pozwalał na większą koncentrację ognia czołowego prowadzonego w kierunku przedpola. Mógł być łączony z elementami starszych systemów fortyfikacyjnych, takich jak kleszczowy czy też bastionowy. Postulowano, aby przed ciągłą linię kurtyn wysuwać samodzielne obiekty (forty detaszowane, lunety), zwiększając w ten sposób głębokość obrony. Dostępu do stanowisk wałowych miały bronić niewielkie kazamaty ukryte w rowach przeszkodowych, tzw. kaponiery. Większe murowane budowle, tzw. redity (Réduit), przeważnie cofnięte za linię wałów, odgrywały rolę silnych śródszańców. Redity funkcjonowały jako schrony koszarowe zintegrowane ze skazamatowanymi stanowiskami bojowymi. Zapewniały możliwość uporczywej obrony bliskiej oraz dalekie wsparcie ogniowe. Działa gładkolufowe rozmieszczone na wyższych kondygnacjach i tarasach redit mogły razić cele na dystansie do 1,5 kilometra.

Pierwszą koncepcję nowych fortyfikacji krakowskich przedstawia zachowany do dziś w archiwum wiedeńskim plan „Lager-Entwurfs-Plan der Befestigung zu Krakau”, datowany na rok $1852^{5}$. Projekt opracował podpułkownik Cornelius Ritter von Wurmb, powołany na stanowisko Dyrektora Krakowskiej Inżynierii w 1850 r. ${ }^{6}$ Wcześniej w latach 1841-1844 kierował Lokalną Dyrekcją Fortyfikacji w Brnie oraz brał udział w kampanii włoskiej ${ }^{7}$.

Krakowski obóz warowny miał się składać z dwóch linii obrony: wewnętrznej linii ciągłych umocnień rdzenia (Noyau) oraz zewnętrznego pierścienia wzajemnie flankujących się fortów reditowych. Forty planowano odsunąć na odległość do 3 kilometrów od zwartej zabudowy miejskiej. Przy granicy z Rosją, 5 kilometrów od miasta, rozważano budowę północnej rubieży obronnej składającej się z kilku silnych dzieł stałych.

Realizacja wewnętrznej linii umocnień wiązała się z szeregiem problemów, których rozwiązanie zajęło władzom wojskowym całą następną dekadę. Kraków,

${ }^{5}$ Kriegsarchiv Wien (dalej: KA), sygn. KPS, GPA, Inland C, VI Krakau nr 3, C. Wurmb, Lager-Entwurfs-Plan der Befestigung zu Krakau, 1852.

${ }^{6}$ C. WurzBach, Biographisches Lexikon des Kaiserthums Österreich (dalej: BLKÖ), Teil. 58, Wien 1889 , s. 288.

7 C. Ritter von Wurmb podczas wojny austriacko-piemonckiej (1848-1849) wznosił fortyfikacje polowe jako Feldgeniedirector bei Südarmee. W dowód zasług odznaczony Krzyżem Zasługi oraz Cesarskim Orderem Żelaznej Korony III Klasy. 
leżący na lewym brzegu Wisły, nie posiadał fortyfikacji liczących się na ówczesnym polu walki. Niegdyśs potężne średniowieczne mury miejskie rozebrano w pierwszej dekadzie XIX w., natomiast kleszczowy obwód Wawelu z 1792 r. nie został ukończony. Miasto otaczała sieć przedmieść, folwarków oraz wiosek rozciągających się wzdłuż promieniście wybiegających z miasta arterii komunikacyjnych. Pasma zabudowy utrudniały realizację rozbudowanych umocnień wokół miasta, szczególnie problem ten dotyczył gęsto zasiedlonej strefy przedmieść północno-zachodnich. Konieczność przymusowego wykupu gruntu oraz wywłaszczania mieszkańców $\mathrm{z}$ ich rodzinnych gospodarstw groziła kolejnymi niepokojami społecznymi. Zwłaszcza że nie chodziło jedynie o wyburzenia posesji w pasie wznoszonych obiektów, ale dodatkowo przewidywano ustanowić stałe strefy ścisłego zakazu budowy w odległości do 700 metrów przed fortyfikacjami ${ }^{8}$. Z kolei obszary nieobjęte intensywnym osadnictwem położone w pobliżu miasta od strony zachodniej i wschodniej były okresowo podtapiane wylewami Wisły oraz jej dopływów. Na zachodzie, od Łobzowa aż po Zwierzyniec rozciągały się rozlewiska bagienne Rudawy nazywane Błoniami. Po drugiej stronie Wisły wieś Dębniki, pokryta starorzeczami, również nawiedzana była regularnie powodziami. Na wschodzie, w stronę Mogiły znajdowały się wsie Dąbie i Grzegórzki, okresowo podmokłe, wykorzystywane jako pastwiska dla zwierząt hodowlanych?. Budowa na tego typu obszarach wymagała regulacji sieci wodnej, przeprowadzenia melioracji oraz stosowania głębokich palowań law fundamentowych. W oczywisty sposób taki stan rzeczy znacznie wydłużał czas realizacji i podnosił koszty zakładanych inwestycji. Jedynie od strony północno-wschodniej suchy wyżynny teren zajęty do tej pory przede wszystkim pod uprawy rolne pozwalał na szybką budowę obwałowań. Podczas Insurekcji Kościuszkowskiej w 1794 r. właśnie w tym rejonie usypano kleszczowe okopy ${ }^{10}$.

Nieco odmiennie sytuacja wyglądała w wypadku sąsiedniego, konkurującego od 1784 r. z Krakowem miasta Podgórza, usytuowanego po prawej stronie Wisły. Miasto wciśnięte w wąski pas terenu między rzecznym korytem a skalistym

${ }^{8}$ Centralne Archiwum Wojskowe, Wojskowe Biuro Historyczne w Warszawie (dalej: CAW), Dowództwo Okręgu Korpusu V (dalej: DOK V), sygn. I.371.5.242, J. KusseniTZ, Ubersicht der Befestigung von Krakau mit dem engen und weiten Bauverboth, K.K. Genie-Direktion zu Krakau, 1863.

9 M. TOBIASZ, Dziejowe przemiany sieci wodnej i zagospodarowania przestrzennego Krakowa, Kraków 1977, s. 69-71.

${ }^{10}$ W okresie funkcjonowania Wolnego Miasta Krakowa okopy kościuszkowskie zostały włączone w skład systemu obwodowych wałów akcyzowych. 
grzbietem Krzemionek było z samej natury rzeczy wręcz predestynowane do pełnienia funkcji przyczółka obronnego. Znajdowała się tu jedyna na przestrzeni dziesiątek kilometrów przeprawa stała, w postaci szerokiego, rozpiętego na kamiennych filarach mostu (im. Franciszka Józefa I), oddanego do użytku 30 grudnia $1850 \mathrm{rr}^{1{ }^{11} \mathrm{~W}}$ pierwszej kolejności umocnienia wymagało górujące nad okolicą wzgórze, które w wypadku rozmieszczenia na nim baterii artyleryjskich dawało możliwość pełnej kontroli przeprawy oraz dwóch prowadzących na południe traktów komunikacyjnych. Od wschodu i zachodu Podgórze osłaniały naturalne przeszkody w postaci podmokłych łąk, stawów oraz starorzeczy.

Biorąc pod uwagę powyższe czynniki, major Wurmb zaproponował założenie wokół Podgórza, Kazimierza i Stradomia linii obrony w postaci wolno stojącego muru pozbawionego fosy ${ }^{12}$. Taki wariant pozwalał uniknąć wyburzeń istniejącej na przedmieściach zabudowy. W centrum swobodnie kształtowanego poligonalnego założenia zbliżonego do trapezu miała się znaleźć Wyspa Kazimierska. Front wschodni wyznaczał wał kolejowy ubezpieczony czterema potężnymi blokhauzami. Front północny łączył pierwszy blokhauz z Zamkiem na Wawelu, następnie front zachodni, otaczając przedmieście Stradom, przecinał Starą Wisłę. Dalej wzdłuż głównego nurtu Wisły mur zmierzał w stronę brzegu podgórskiego, tam zmieniał kierunek, wspinając się po stromych stokach Krzemionek. Biegnąc grzbietem wzgórza na tyłach wież artyleryjskich, linia obronna zamykała 5-kilometrowy obwód, łącząc się z południowym blokhauzem przy wale kolejowym. Ostrzał flankujący miały zapewnić rozmieszczone wzdłuż muru niewielkie kaponiery, zapewne zbliżone formą do tych zrealizowanych po 1853 r. na Wawelu. Co ciekawe, nie przewidywano zamknięcia samego Krakowa podobnym murem poligonalnym. Potencjalne przejęcie fortyfikacji przez polską ludność mogło przedłużyć opór i utrudnić tłumienie nowej rewolty. Nadal obawiano się buntu, mając świeżo w pamięci rok 1848, wznoszenie barykad oraz krwawe walki na ulicach miasta.

Ostatecznie pierwsza koncepcja Noyau pozostała jedynie na papierze. Koszt realizacji długich murowanych odcinków mógł okazać się wysoki, natomiast skuteczność obrony wątpliwa. Tego typu umocnienia wystarczały jedynie do

${ }^{11}$ D. Lulewicz, O kolei i mostach w Podgórzu, [w:] Dwa miasta, dwa brzegi w 100. rocznicępotaczenia Podgórza i Krakowa (1915-2015), red. E. FiRLET, Kraków 2015, s. 257.

${ }^{12} \mathrm{KA}$, sygn. KPS, GPA, Inland C, VI Krakau, nr 3, C. Wurmb, Lager-Entwurfs-Plan der Befestigung zu Krakau, 1852. 
odparcia niespodziewanego ataku piechoty czy kawalerii, natomiast podciągnięte baterie dział przeciwnika szybko wykonałyby wyłomy w nieosłoniętych przedstokami kurtynach. Kraków jeszcze przez kilka lat pozostał miastem „otwartym”, opasanym jedynie wałami akcyzowymi nieposiadającymi praktycznie żadnego znaczenia militarnego.

Zewnętrzną, a zarazem pierwszą linię fortyfikacji krakowskiego obozu warownego stanowić miał pierścień 34 wież i fortów, zlokalizowanych na obu brzegach rzeki Wisły ${ }^{13}$. Typologicznie przypominały elementy obronne zrealizowane na przełomie lat czterdziestych i pięćdziesiątych XIX w. w twierdzy Ołomuniec na Morawach. Natomiast znaczna liczba proponowanych obiektów nasuwa skojarzenia z umocnieniami miasta Linz, gdzie w latach 1831-1835 zbudowano 32 wolno stojące wieże artyleryjskie oraz jeden duży fort poligonalny ${ }^{14}$. W Krakowie dzieła pierścienia zamierzano rozstawić maksymalnie co 1 kilometr, przeważnie na kulminacjach wzniesień. W ten sposób zapewniono możliwość wzajemnego wsparcia ogniowego prowadzonego z użyciem ówczesnych armat gładkolufowych. Wykup gruntów na tak odległych i niezamieszkałych obszarach nie stanowił większego problemu, co usprawniło proces decyzyjny i ułatwiało rozpoczęcie konkretnych prac terenowych.

Budowę trzech pierwszych punktów oporu rozpoczęto w najważniejszych pod względem strategicznym miejscach. Rozległy fort cytadelowy 2 od $1850 \mathrm{r}$. powstawał wokół kopca Kościuszki ${ }^{15}$, po zachodniej stronie Krakowa na wzgórzu nad traktem prowadzącym w stronę Oświęcimia. W tym samym roku na północy zaczęła się budowa mniejszego fortu reditowego 12 osłaniającego gościniec warszawski ${ }^{16}$ wraz z końcowym odcinkiem linii kolejowej C.K. Wschodniej Kolei Państwowej. Natomiast stronę południową z Podgórzem miał ubezpieczać kamienny szaniec 33 rozbudowywany od 1849 r. przy starożytnym kopcu $\mathrm{Kraka}^{17}$. Numery porządkowe przypisane powstającym obiektom wynikały z wcześniej przewidzianej w projekcie Wurmba liczby umocnień zewnętrznych. Punkty, w których zlokalizowano dzieła obronne, utworzyły trójkąt o podsta-

13 Ibidem.

14 E. Hillbrand, Turme von Linz, [w:] Historisches Jabrbuch der Stadt Linz, Archiv der Stadt Linz, 1985, R. 1984, s. 194-197.

15 CAW, DOK V, sygn. I.371.5.74, Erbaungsdaten der Befestigungsobjekte der Lagerfestungs Krakau, K.u.K. Geniedirektion in Krakau, 1909, k. 1.

16 Ibidem.

17 Kraków 17 lipca, „Gazeta Warszawska” 1849, nr 191, s. 1. 
wie 5 kilometrów (linia między obiektami 2 i 33) oraz ramionach zbiegających się w centrum Lunety 12 o długości blisko 4,5 kilometra. W geometrycznym środku tak wyznaczonej figury znalazła się zwarta zabudowa Krakowa wraz z Wawelem pełniącym funkcję Cytadeli.

W latach 1853-1855 podczas mobilizacji wywołanej wojną krymską rozpoczęto realizację kolejnych zewnętrznych umocnień krakowskich oraz intensywnie rozbudowywano infrastrukturę kolei żelaznej. Groźba wojny z Rosją wymusiła pośpieszną realizację wieńca 25 szańców polowych w miejscach zaplanowanych wcześniej dzieł stałych ${ }^{18}$. W tym okresie powstaje również druga koncepcja Noyau.

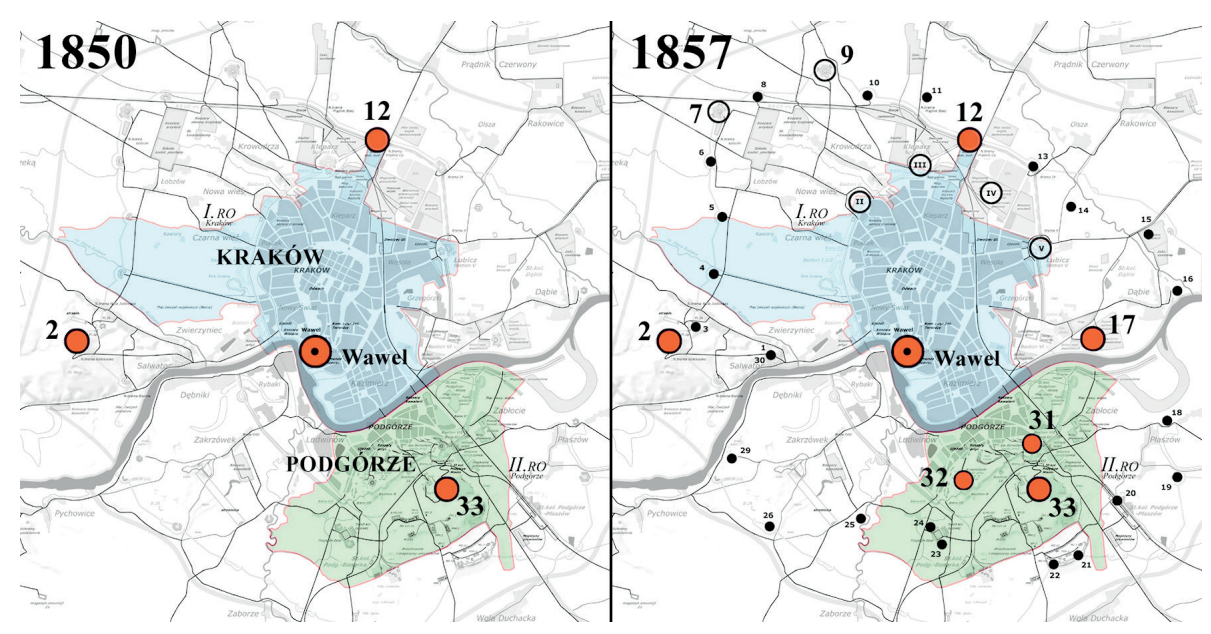

Ryc. 1. Dwie pierwsze fazy budowy umocnień krakowskiego obozu warownego. Początek I rozbudowy - 1850 r. oraz II - 1857 r. Czerwone punkty - forty stałe, czarne - szańce polowe, białe koła - bastiony Noyau II-V, forty wysunięte 7 i 9 (oprac. P. OPALIŃSKI)

Nowy plan koncepcyjny twierdzy krakowskiej parafowany został przez generała Bernharda Graf von Cabogę w sierpniu 1855 r. we Lwowie ${ }^{19}$. Pochodzący z dalekiej Republiki Ragusy (Dubrownik) arystokrata, uznany fortyfikator doby wojen napoleońskich, od 1832 r. służył w wiedeńskiej General-Geniedirektion, współtworzył szereg umocnień w północnych Włoszech, Dalmacji, Czechach i na Morawach. Jako Naczelny Inspektor Inżynierii od 1849 r. odpowiadał za

${ }^{18} \mathrm{KA}$, sygn. KPS, GPA, Inland C, VI Krakau, nr 23, C. Wurmb, Plan der Lagerverschanzung von Krakau, 1855.

19 KA, KPS, GPA, Inland C, VI Krakau, nr 4, Schichten Plan der Umgebungen von Krakau, 1855. 
wszystkie projektowane i rozbudowywane twierdze na obszarze Cesarstwa Austrii ${ }^{20}$. Plan Cabogi przedstawiał rdzeń otaczający Kraków wraz z przedmieściami niemal regularnym okręgiem opartym o rzekę Wisłę. Hybrydowa koncepcja dwóch systemów fortyfikacyjnych, bastionowego i poligonalnego, wyraźnie nawiązywała do idei zgeometryzowanych renesansowych miast idealnych. Na krakowskim brzegu wyznaczony obwód miał 5,5 kilometra długości. Dwanaście fortów reditowych pełniących funkcje bastionów rozmieszczono w niemal równych 500-metrowych odstępach. Bastiony o wydłużonych czołach i krótkich barkach miały posiadać murowane skarpy pozbawione kaponier. Elementy flankujące pojawiają się dopiero w rozbudowanych szyjach, zapewniając tym samym skryty ogień przestrzeliwujący proste odcinki kurtyn. W pięciu przypadkach w centrum bastionów za wałem artylerii umieszczono półkoliste redity - działobitnie. Dwa dzieła o numerach 1 i 12 zlokalizowane przy brzegu Wisły uzyskały formę półbastionów z pojedynczymi kaponierami szyjowymi. Kurtyny łączące bastiony na frontach północnym oraz wschodnim miały być zaopatrzone w stanowiska artylerii wałowej. Od zachodu kurtyny ze względu na obecność dużych rozlewisk (a przez to mniej prawdopodobną możliwość ataku wroga) proponowano wykonać w formie odcinków murów obsadzonych jedynie przez żołnierzy piechoty. Ochronę skarp umożliwiały w tym wypadku zewnętrzne słoniczoła. Rowy przeszkodowe na całym obwodzie miały dochodzić do 80 metrów szerokości. Dodatkową obronę zewnętrzną miały zapewnić wolno stojące murowane blokhauzy usytuowane przy placach broni drogi krytej.

Podgórze miało zabezpieczyć 6 bastionów, których kurtyny tworzyły wydłużony czworobok. Północno-wschodni front, podobnie jak w poprzedniej koncepcji, miał biec w linii wału kolejowego. Przy nadwiślańskim składzie solnym i moście kolejowym przewidywano budowę dużej redity, a dalej w narożniku wschodnim rozcięty torami bastion 13. Górski front południowo-wschodni tworzyły poligonalne mury w formie bastionów (12-17) o skazamatowanych barkach. Od strony przedpola osłonięte zostały rowami, przedstokami oraz parą wież artyleryjskich. Południowo-zachodni bok Noyau prawobrzeżnego wspierał fort reditowy (bastion 18), pilnujący początkowego odcinka traktu wiedeńskiego.

Kazimierz od zachodu chronić miały dwa niewielkie bastiony, przy wapienniku w pobliżu ulicy Skawińskiej (19) oraz przed kościołem na Skałce (20).

${ }^{20} B L K O ̈$, Wien 1857, Bd. 2, s. 223. 
Kurtyny ziemno-murowane jak we wcześniejszym projekcie biegły w stronę kleszczy wawelskich (zamek opisano na planie Cabogi jako Castell z numerem 21). Po drugiej stronie wzgórza zamkowego poligonalny wał (22) łączył się $\mathrm{z}$ lewobrzeżnym półbastionem 1 . W sumie cały obwód Noyau miał mieć 10 kilometrów długości.

Po śmierci generała von Cabogii ${ }^{21}$ odpowiedzialność za realizację przedsięwzięcia spoczęła na Corneliusie von Wurmbie. Kilka kolejnych wersji koncepcyjnych zamyka projekt rdzenia datowany na 3 lutego 1857 r., skierowany ostatecznie do realizacji ${ }^{22}$. Obwód został powiększony o 0,5 kilometra na odcinku północno-zachodnim. Na przeszkodzie ekspansji obwałowań w stronę północno-wschodnią stanął cmentarz Rakowicki ${ }^{23}$. W rezultacie zmian w projekcie zaburzony został pierwotnie zakładany regularny układ założenia. Liczbę bastionów lewobrzeżnych zredukowano do 7, z czego tylko 5 miało mieć charakter silnych fortów reditowych (I - za przedmieściem Smoleńsk, II - przed Nową Wsią, III - za Kleparzem, IV - przed cmentarzem Rakowickim i V - za przedmieściem Wesoła). Każdy z fortów-bastionów został dodatkowo wyposażony w podwójne kaponiery na styku czół i barków oraz wewnętrzne dostawione do ścian elewacyjnych półkolistych redit. Czoła bastionów skrócono, jednocześnie powiększając kubatury szyjowych kazamat flankujących. Fort-bastion I za pomocą śluzy umieszczonej w szyi miał kontrolować poziom wody w fosach zachodnich. Fosy postanowiono zawęzić. Kurtyny na wszystkich frontach zamierzano wyposażyć w stanowiska dział osłonięte ziemnymi przedpiersiami. Zrezygnowano natomiast $\mathrm{z}$ zewnętrznych blokhauzów przy drodze krytej. Na planie, w środkowej części niezwykle długiej poligonalnie łamanej kurtyny I-II leżącej na wprost Błoń, dodano informacje o zamiarze lokalizacji zaplecza magazynów prowiantowych twierdzy ${ }^{24}$. Po raz pierwszy pojawia się propozycja umieszczenia dużego zespołu koszarowego za bastionem V przy ul. Lubicz, na wschód od Dworca Głównego. Komunikację z fortem detaszowanym 12 „Luneta Warszawska” usytuowanym przed kurtyną III-IV miała zapewnić droga

\footnotetext{
${ }^{21}$ General-Feldzeugmeister Berhard Graf von Caboga, zmarł w Wiedniu 19 XI 1855 r.

${ }^{22}$ KA, KPS, GPA, Inland C, VI Krakau, nr 24, Situationsplan. Projectirten Anlagen der Befestigung von Krakau, Genie Direktion Krakau, 1857.

${ }^{23}$ Cmentarz generalny nazwany później Rakowickim założono na terenie folwarku Bosackie w $1802 \mathrm{r}$.

${ }^{24}$ W 1863 r. rozpoczęto w tym miejscu budowę bastionu I w połowie wypełniającego zbyt dużą przestrzeń między bastionami I i II. Dzisiejszy rejon skrzyżowania ul. Krupniczej z al. A. Mickiewicza.
} 
kryta o długości 450 metrów. Na zewnątrz ciągłej linii umocnień ukończono również fort 17 „Luneta Grzegórzecka” ${ }^{25}$ oraz zdecydowano o rozpoczęciu prac przy znacznie większych dziełach reditowych o numerach 7, 9 i 15.

Program rdzenia na odcinku kazimierskim oraz prawobrzeżnym w zasadzie powtarzał wcześniej opisaną koncepcję. Zmieniono jedynie numerację obiektów (IX-XVIII) oraz zredukowano program bastionów wschodniego IX (wcześniej opisywany jako 13) i zachodniego XIII (18). Bliźniacze wieże 31 „św. Benedykt” oraz 32 „Krzemionki” ukończono w 1856 r. Murowane koliste działobitnie o wysokości 15,5 metra posiadały trzy kondygnacje (pierwsza ze stanowiskami karabinowymi, druga skazamatowana dla artylerii i trzecia $\mathrm{w}$ formie ziemnego tarasu $\mathrm{z}$ hangarem na działa wałowe ${ }^{26}$. Pomiędzy drogą prowadzącą do magazynów solnych a linią kolejową proponowano zbudować arsenał, formą przypominający ukończony w tym samym czasie kompleks zbrojowni wiedeńskiej.

\section{Budowa rdzenia lewobrzeżnego}

Realizację umocnień Noyau rozpoczęto na najbardziej zagrożonym odcinku północnym ${ }^{27}$. Bastiony od II do V usytuowane na pozbawionym większych przeszkód naturalnych terenie miały stanowić najsilniejsze ogniwa obrony Krakowa. W 1857 r. prowadzono prace ziemne przy kopaniu fos i formowaniu wałów w miejscach przyszłych dzieł III i V. Do końca października 1859 r. postawiono ceglane mury skarpowe wzdłuż czół i barków obydwu bastionów, ściany kaponier wymurowano do poziomu strzelnic, założono dolne partie potern komunikacyjnych. Ustawiono ławy fundamentowe redit, wykonano podpiwniczenia oraz dolne odcinki murów szyjowych ${ }^{28}$.

W 1859 r. na stanowisku Dyrektora Krakowskiej Inżynierii zastąpił Corneliusa von Wurmba pułkownik Conrad Petrasch, pełniący do tej pory funkcję

${ }^{25}$ Fort 12 ukończono w 1856 r., natomiast fort $17 \mathrm{w} 1857 \mathrm{r}$.

26 P. OpalińsKi, Austriackie fortyfikacje Podgórza w latach 1790-1859, [w:] Miasto pod kopcem Kraka, red. E. FirLET, Kraków 2016, s. 220-222.

${ }^{27}$ CAW, DOK V, sygn. I.371.5.265, Wykaz fortów, obronnych punktów i składów wojennych amunicji w byłej twierdzy Krakowa z 1 VIII 1919 r., k. 4.

${ }^{28}$ CAW, DOK V, sygn. I.371.5.234, Gewirkte Erd und Maurer Arbeit bis Ende Oktober 1860 - Rapports-Plan Litt: C der Bastion III, K.K. Genie Direktion zu Krakau. 
Inspektora Inżynierii Fortecznej Chorwacji i Slawonii ${ }^{29}$. W tym samym roku wybuchł konflikt austriacko-francuski, kolejna wojna o dominację w północnych Włoszech. Na polu walki pojawiła się nowa broń w postaci dział odtylcowych o gwintowanych lufach. Wzrosły szybkość oddawanych strzałów, siła oraz zasięg prowadzonego ognia artylerii. Wystrzelone z odległości 3000 metrów pociski nowych dział były w stanie zniszczyć budowane do tej pory struktury obronne ${ }^{30}$.

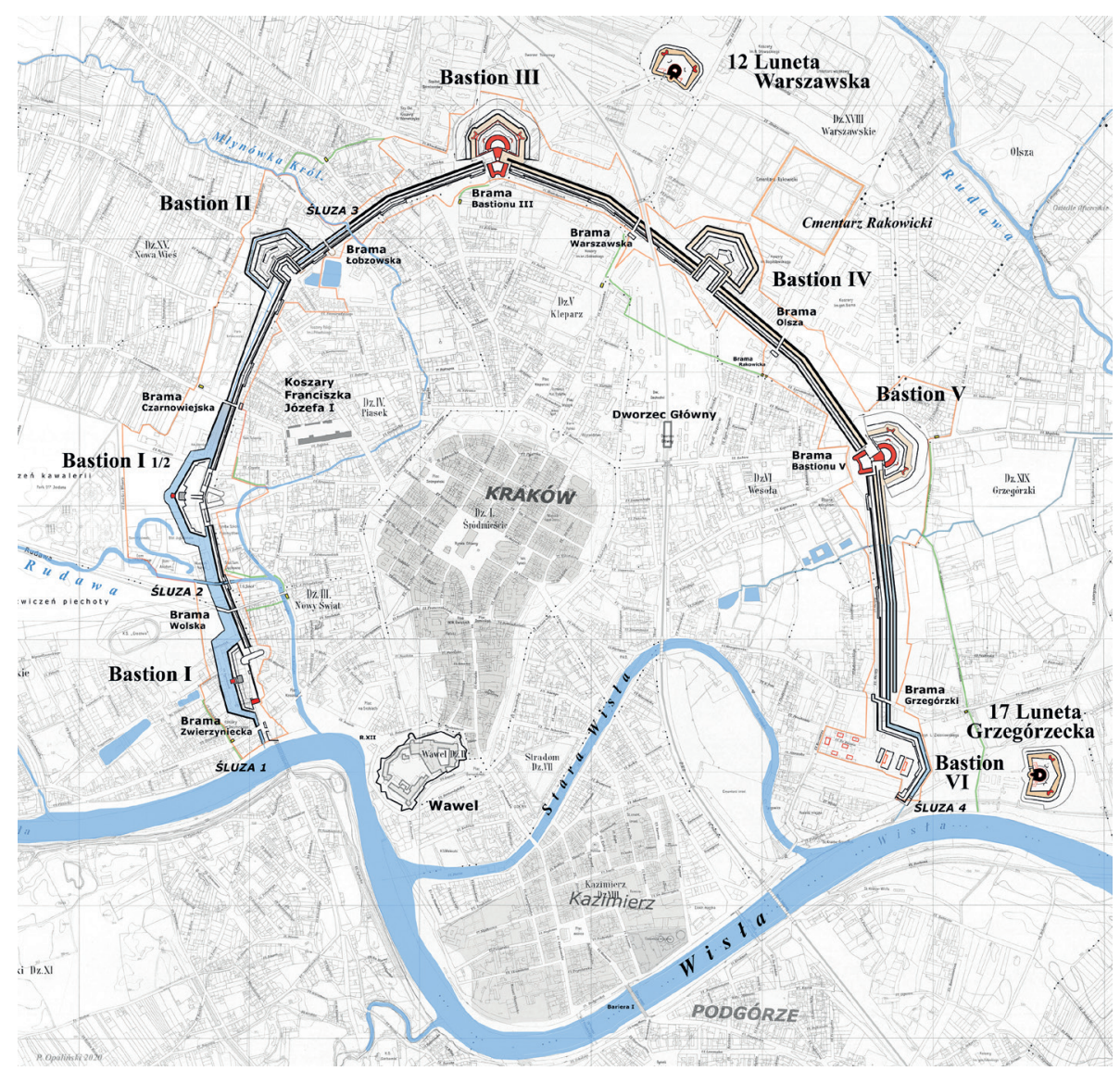

Ryc. 2. Noyau lewobrzeżne (krakowskie) według stanu z 1866 r. - rzut rekonstruowany na podkładzie geodezyjnym miasta w skali 1:10 000 z 1936 r. (oprac. P. OPALIŃSKI)

29 Österreichisches Biographisches Lexikon 1815-1950, Österreichische Akademie der Wissenschaften, Wien 1983, Bd. 8 (Lfg. 36, 1979), s. 1.

${ }^{30}$ F. ForstNer, op. cit., s. 54. 
W odpowiedzi na kryzys w fortyfikacji na początku sezonu budowlanego 1860 r. prace w Krakowie wstrzymano, a znaczne fragmenty dopiero ukończonych kubatur wyburzono. Redity wymagały obniżenia, rezygnowano z elementów takich jak machikuły, smukłe neogotyckie wieżyczki czy ozdobne krenelaże. Narażone na ostrzał z dalekiego przedpola ściany osłaniano dodatkowymi wałami ziemnymi, sklepienia zaś nakrywano grubymi nasypami. Analiza archiwalnych planów wykonawczych bastionów III i V wskazuje również na modyfikowanie ich elementów w trakcie realizacji. Zmiany widać zwłaszcza w konstrukcji narożników flankujących fosę kaponier ${ }^{31}$, w rozplanowaniu strzelnic czy grubości ścian kazamat. Pomimo trudności prace budowlane pod nadzorem Petrascha zintensyfikowano, w wypadku bastionu V udało się do końca października 1860 r. wykonać większą część kubatur kaponier czołowych, dwukondygnacyjnej redity oraz szyjowych kazamat flankujących ${ }^{32}$. $\mathrm{Na}$ bastionie III postęp robót był wolniejszy, powstały jedynie kaponiery czolowe oraz pozbawione sklepień dolne piętro redity ${ }^{33}$.

Budowę wznowiono wiosną 1861 r. ponownie na najbardziej zaawansowanym odcinku północnym ${ }^{34}$ oraz rozpoczęto prace melioracyjne i ziemne na odcinku zachodnim rdzenia. Bastion V otrzymał podwójną kaponierę szyjową w linii przyszłych kurtyn, natomiast bastion III drugą kondygnację redity i poterny łączące dziedziniec z kaponierami. Zakres przeprowadzonych prac można zobaczyć na wykonanej w skali 1:28 800 mapie topograficznej Galicji i Bukowiny z lat 1861-186453. Na planie zaznaczono płaszczyzny glacis uformowane z materiału wybranego z rowów przeszkodowych, dolne partie murowanych stoków, redit oraz kaponier. Linią przerywaną przedstawiono przebieg wytyczanych dopiero odcinków wschodnich i zachodnich Noyau. Robót przy bastionie II jeszcze nie zaczęto, prawdopodobnie ze względu na istniejącą w tym miejscu zabudowę Nowej Wsi oraz stawy rybne na Piasku wymagające niwelacji.

${ }^{31}$ CAW, sygn. DOK V, sygn. I.371.5.254, Situations-Plan. Bastion No.V, Befestigungs-Bau zu Krakau, 1856.

32 CAW, sygn. DOK V, sygn. I.371.5.254, Profile zum Rapports-Plan fur das Jahr 1860, K.K. Genie-Direktion zu Krakau.

${ }^{33}$ CAW, sygn. DOK V, sygn. I.371.5.234, Rapports-Plan der Bastion III, K.K. Genie Direktion zu Krakau.

${ }^{34}$ CAW, sygn. DOK V, sygn. I.371.5.74, Erbaungsdaten der Befestigungsobjekte der Lagerfestungs Krakau, K.u.K. Geniedirektion in Krakau, 1909, k. 2.

${ }^{35}$ Galizien und Bukowina, Franziszeische Landesaufnahme 1861-1864, vide: https://mapire.eu/ en/map/secondsurvey-galicia (dostęp: 9 I 2021). 
Kolejnym szefem Dyrekcji Inżynierii w Krakowie został podpułkownik Joseph Kussenitz Ritter von Ibenics w 1862 r. ${ }^{36}$ Doświadczenie zdobył, kierując rozbudową włoskich twierdz Piacenza i Mantua. W latach czterdziestych XIX w. uczestniczył w fortyfikowaniu Eszegg, Alt-Gradisca oraz Kotoru.

W 1863 r. ukończono śluzę na Rudawie oraz zainicjowano roboty murarskie przy bastionach I oraz I $1 \frac{1}{2}$. Po kolejnych trzech latach prac w 1865 r. zakończono główne elementy bastionu III. Zrezygnowano z wykonania redit i skazamatowanych kaponier przewidzianych w dwóch dziełach frontu zachodniego. Prawdopodobnie grunt w strefie dolnej terasy wiślanej okazał się zbyt niestabilny, co groziło zapadaniem się podłoża pod masywnymi ceglanymi kubaturami. Efektem osiadania fundamentów mogła być katastrofa budowlana podobna do tej, jaka dotyczyła redity fortu 17 „Luneta Grzegórzecka” ${ }^{37}$. Bastiony II i IV ostatecznie postanowiono wykonać w formule dzieł półstałych. Ich wały miały zostać ubezpieczone jedynie linią palisad oraz zapór przeciwszturmowych. Uporczywą obronę zapewniały cofnięte za linię szyi śródszańce w formie ziemnych redanów. Natomiast osłonięte nasypami ukrycia dla załogi miały powstać dopiero w okresie mobilizacji twierdzy.

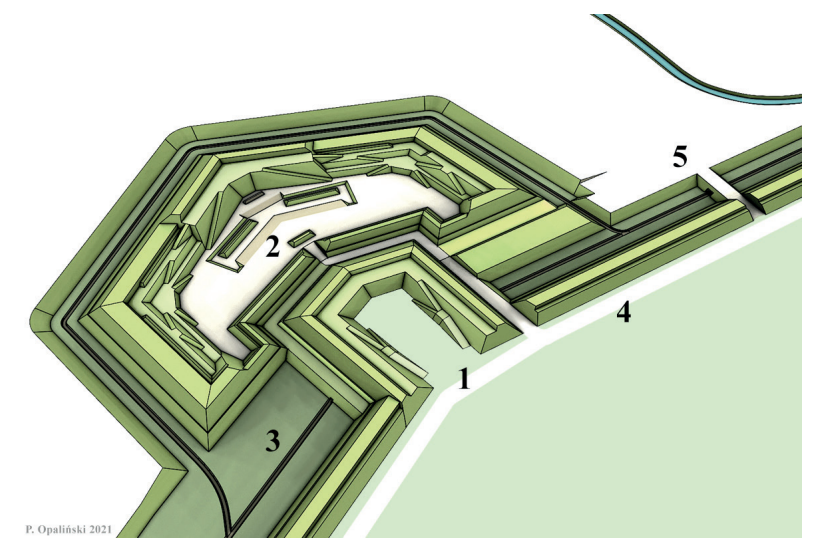

Ryc. 3. Rekonstrukcja cyfrowa bastionu II według stanu z 1866 r. Widok perspektywiczny od strony południowej. 1 - ziemny śródszaniec w szyi bastionu, 2 - dziedziniec bastionu z miejscem przeznaczonym na budowę schronu ziemno-drewnianego dla załogi, 3 - fosa z kanałami odprowadzającymi nadmiar wody, 4 - obwodowa droga wałowa, 5 - przejazd przez wał, brama "tobzowska" (oprac. P. OpALIŃSKI)

${ }^{36}$ Militärschematismus des österreichischen Kaiserthumes für 1861-1862, Wien 1862, s. 486.

37 CAW, DOK V, sygn. I.371.5.239, Rapports-Plan. Demolirungs - Arbeiten fur das Jahr 1860, K.K. Genie Direktion zu Krakau. 
Przebieg ziemnych kurtyn łączących bastiony również uległ korekcie. Na zachodzie wprowadzono jeden bastion o numerze I $1 / 2$, a na froncie wschodnim usunięto dwa. W kurtynach skorygowano sposób rozmieszczenia stanowisk artylerii. Ławy działowe sypano tylko w załamaniach wałów oraz na skrzydłowych pozycjach poszczególnych bastionów. Wyjątkiem była kurtyna pomiędzy dziełami IV i V, gdzie na całej długości odcinka istniała możliwość ustawienia armat prowadzących ostrzał w kierunku Olszy i Rakowic. Szerokość wałów kurtynowych wynosiła średnio 20 metrów, szerokość rowów przeszkodowych na frontach północno-zachodnich i północno-wschodnich - około 22 metrów, głębokość do 5 metrów. Odcinki płytszych fos wschodnich i zachodnich, które mogły być napełniane wodą, dochodziły do 45 metrów szerokości i 3 metrów głębokości. Zrezygnowano z wykonania płaszczyzn glacis na zewnątrz rowów przeszkodowych wszystkich kurtyn ${ }^{38}$.

Ostatecznie zakończono formowanie rdzenia lewobrzeżnego w 1866 r. w trakcie trwania wojny austriacko-pruskiej. W tym roku powstało ostatnie dzieło VI o uproszczonej formie załamanego na podobieństwo bastionu wału ziemnego. Ciągły poligonalny obwód obronny miał 6 kilometrów długości, powstało 7 bastionów, z czego 2 były fortami reditowymi, 2 posiadały murowane prochownie i elementy flankujące oraz 3 pozostały dziełami ziemno-drewnianymi. Komunikację zapewniało 9 przejazdów w kurtynach, zabezpieczonych cofniętymi odcinkami wałów lub dziedzińcami ogrodzonymi palisadą. Poziom wody w fosach regulowały cztery śluzy.

Zmobilizowaną twierdzę krakowską wyposażono w 427 dział różnego typu, z czego 108 znalazło się na umocnieniach Noyau. Bastion I uzbrojony został w 4 armaty, bastion I 1/2 - w 6 armat, bastion II - w 13 armat, na stanowiskach w kurtynach frontu zachodniego ustawiono 6 armat. Bastion III wyposażono w 27 armat, bastion IV w 11 armat i 4 moździerze (30- i 60-funtowe), bastion V - w 26 armat oraz bastion VI - w 4 armaty. Wśród dział umieszczonych na obiektach od II do V znalazły się 4 ciężkie armaty 30-funtowe, po jednej na każdy bastion ${ }^{39}$.

Rdzeń prawobrzeżny w latach sześćdziesiątych XIX w. nie doczekał się planowanej realizacji. Nadal funkcjonowała jedynie obrona punktowa w postaci wież artyleryjskich, pilnujących traktu wiedeńskiego i lwowskiego.

38 CAW, DOK V, sygn. I.371.5.238, Plan der Hauptumfassung Krakaus in ihrem jetzigen Bestande und des Verzehrungssteuer Linien - Walles.

39 KA, sygn. FA AFA HR Akten 2307, Armierungs Ausweis zum 28 August 1866 - 1866 III - VIII und X und XIII Festung Krakau, K.K. Festungs Comando Krakau, 1866. 
Od południa wzmacniał obronę wysunięty górski fort 33 „Krakus”. W okresie mobilizacji 1866 r. wykonano tylko dwa ziemne, prowizoryczne odcinki wałów - od wschodu między linią kolejową a skalistym podnóżem wieży 33 oraz od zachodu między Wisłą a dzisiejszą ulicą Stromą. Na forcie 33 i dwóch wieżach krzemionkowskich ustawiono na każdym z obiektów po 8 dziat ${ }^{40}$.

Całkowity koszt zrealizowanych do końca 1868 r. umocnień krakowskich obejmujących Noyau oraz stałe i polowe fortyfikacje szacowany jest na 11 milionów koron. Kwoty dotyczące poszczególnych obiektów rdzenia nie są nadal w pełni znane. Do wyjątków należą bastion III - koszt: 1446996 koron, bastion V - 1750032 korony oraz wieże 31 i 32 - odpowiednio 263702 korony i 288688 koron $^{41}$.

Na brzegu krakowskim garnizon zajmował budynki na Zamku Wawelskim zamienionym na Cytadelę. W latach 1855-1862 wzniesiono tam nowe koszary, stajnie oraz szpital według projektów Feliksa Księżarskiego. Przy ul. Rajskiej w 1862 r. zbudowano okazały gmach koszar im. Franciszka Józefa I. Dawny zrujnowany Pałac Królewski w Łobzowie przebudowano w latach 1852-1853 na szkołę wojskową $^{42}$. Dla garnizonu oraz mieszkańców miasta zbudowano w tym okresie zespół klinik medycznych przy ulicy Kopernika. Na terenie Podgórza wojsko zostało rozlokowane w adaptowanych na cele wojskowe byłych magazynach solnych (Salinengebäude), stacjonowały tam jednostki piechoty i kawalerii. Gmach Oekonomie-Gebäude przy ul. Kalwaryjskiej, w którym od końca XVIII w. mieściły się urzędy rządowe, zmieniono w koszary kawaleryjskie, a w latach późniejszych artyleryjskie. Obok powstała kryta ujeżdżalnia koni wojskowych ${ }^{43}$. Przy ulicy Skawińskiej na Kazimierzu powstał w latach pięćdziesiątych XIX w. szpital wojskowy.

Inwestycje wojskowe prowadzone w Krakowie oraz Podgórzu miały istotne znaczenie dla gospodarki miejskiej. Powstały nowe cegielnie, piece wapiennicze, kuźnie, uruchomiono kamieniołomy dostarczające materiały budowlane. Kilka tysięcy miejscowej ludności znalazło zatrudnienie przy pracach murarskich oraz niewymagających szczególnych kwalifikacji olbrzymich robotach ziemnych prowadzonych pod nadzorem wojskowych specjalistów.

\section{Ibidem.}

41 M. Mikulski, Kilka stów o kosztach budowy Twierdzy Kraków, „Cztery Historie” 2011, t. 1.

42 M. Mikulski, J. Środulska-Wielgus, K. Wielgus, D. Pstuś, Obronność Krakowa w XIX i XX wieku jako element rozwoju miasta, [w:] Kraków. Nowe studia nad rozwojem miasta, red. J. WYROZUMSKI, Kraków 2007, s. 814.

43 Według informacji podanych na planie z ok. 1856 r. - autor nieznany, podkład kartograficzny A. KocziczKi: KA, KPS, GPA, Inland C, VI Krakau, nr 21, Plan von Krakau mit Podgorze, Olmutz 1847. 


\section{Geometria narysu}

Jak wcześniej podkreślono, system fortyfikacji poligonalnych nie wymagał zastosowania układów podporządkowanych sztywnym zasadom geometrycznym. Tego typu narysy „twierdz idealnych” realizowano raczej między XVI a XVIII w., czego przykładem mogą być miasta-twierdze takie jak włoska Palmanova, francuskie Neuf-Brisach czy pruska cytadela w Grudziądzu. Do wyjątkowo regularnie zgeometryzowanych obiektów tego typu z pierwszej połowy XIX w. należą rdzeń i cytadela twierdzy Poznań, projekt gen. Ernsta von Astera z 1840 r. ${ }^{44}$ Co prawda generał Bernhard von Caboga w 1855 r. przedstawił równie regularne rozwiązanie przestrzenne Noyau krakowskiego, lecz warunki topograficzne, jak i budżetowe wymusiły modyfikacje projektu kontynuowanego przez Corneliusa von Wurmba oraz jego następców.

Analizując archiwalne rzuty zrealizowanego rdzenia lewobrzeżnego, można odnaleźć interesujące zależności geometryczne elementów frontu północnego. Przedłużając w kierunku południowym oś symetrii bastionu III oraz oś symetrii fortu 12 „Luneta Warszawska”, otrzymamy w miejscu ich przecięcia punkt A. Kąt między obiema prostymi wynosi $28^{\circ}$. Obracając kolejne proste względem punktu A o ten sam kąt, otrzymamy trzy osie wyznaczające załamania kurtyn oraz lokalizację bastionów II i IV.

Drugą zależność znajdziemy, przedłużając oś symetrii bastionu IV. Przecięcie z osią bastionu III wyznaczy punkt B, znajdujący się w wyższej wieży kościoła Mariackiego. Między osiami odczytamy kąt $38^{\circ}$. Odkładając ten sam kąt lustrzanie względem osi bastionu IV, uzyskamy prostą wyznaczającą załamanie kurtyn w miejscu szyi bastionu V. Odległość między centralnym punktem redit dzieł III i V a wieżą mariacką wynosiła 1490 metrów. W tym miejscu warto nadmienić, że w wypadku Poznania osie wszystkich 6 bastionów zbiegały się w jednym punkcie. Promień półkolistego otaczającego miasto Noyau Astera wynosił 1070 metrów ${ }^{45}$. W odniesieniu do zachodniego i wschodniego odcinka rdzenia krakowskiego nie udało się stwierdzić już tak wyraźnych geometrycznych zależności.

${ }^{44}$ J. Biesiadka, A. Gawlak, S. Kucharski, M. Wojciechowski, Twierdza Poznań. O fortyfikacjach miasta Poznania w XIX i XX wieku, Poznań 2006, s. 25.

45 Ibidem, s. 37. 


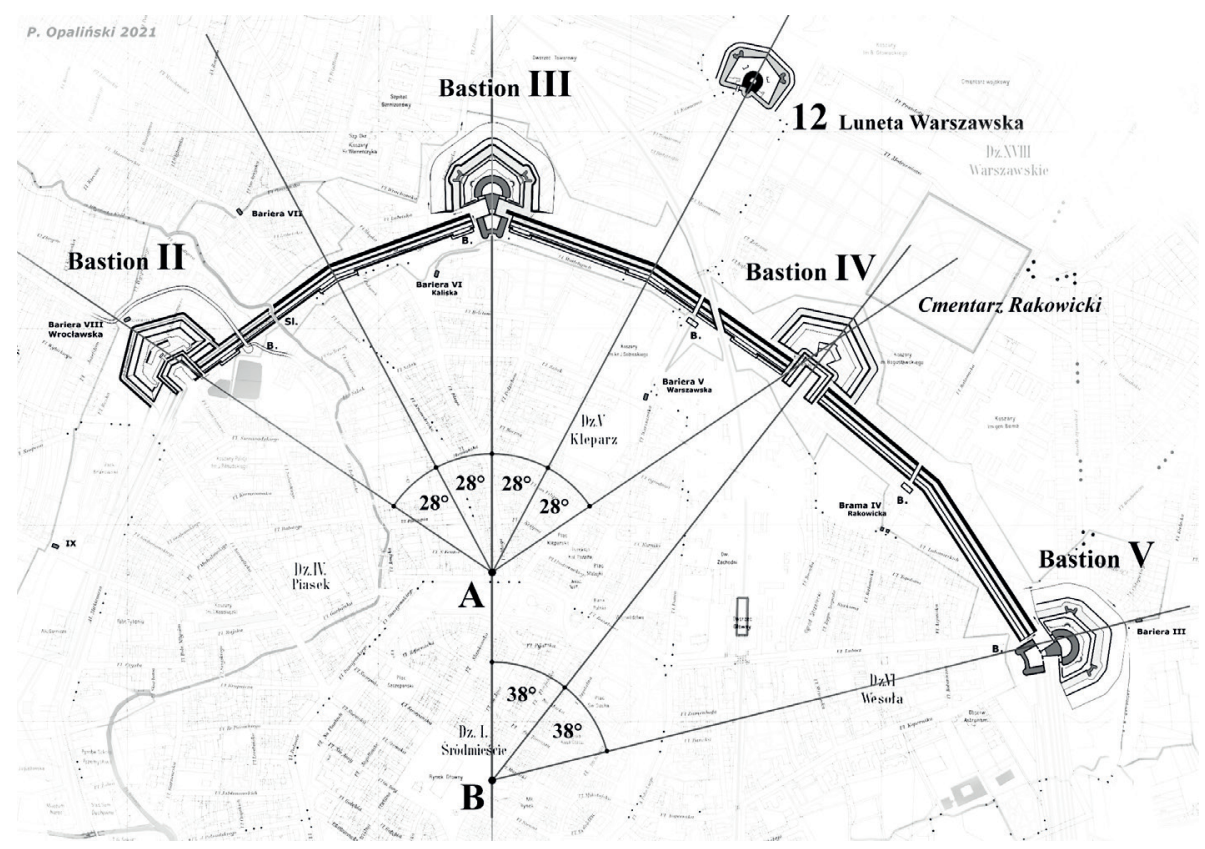

Ryc. 4. Geometria narysu północnego odcinka Noyau krakowskiego (oprac. P. OPALIŃSKI)

\section{Rozbudowa rdzenia na krakowskim i podgórskim brzegu Wisły}

Do ponownej rozbudowy umocnień doszło w latach 1887-1888 pod kierownictwem podpułkownika Carla Freiherr von Schallera ${ }^{46}$. Tym razem powiększono obwód po stronie północno-wschodniej, łącząc wspólnym wałem fort 12 „Lunetę Warszawską” oraz przebudowany szaniec polowy 13. Wewnątrz rdzenia znalazł się duży teren wraz z cmentarzem Rakowickim ${ }^{47}$.

Stopniowo w kolejnych latach wypełniono pozyskany obszar zespołem magazynów, warsztatów, składów materiałowych i koszar, tworząc jeden z większych fortecznych zespołów garnizonowych i aprowizacyjnych monarchii austro-węgierskiej. Stały garnizon krakowski liczył pod koniec lat osiemdziesiątych

\footnotetext{
${ }^{46}$ Kais. Königl. Militär-Schematismus 1888, Wien, 1887, s. 728.

${ }^{47}$ CAW, DOK V, sygn. I.371.5.239, Noyau zwiechen Bastion IVa - VI, Festungskommando Krakau.
} 
XIX w. około 6 tys. żołnierzy różnych formacjii ${ }^{48}$. Koroną wałów rdzenia poprowadzono obwodową kolej żelazną ${ }^{49}$. Przed przejazdami w wale ustawiono masywne ceglane bramy forteczne zamykane żelaznymi furtami. Obsada miała liczyć 1791 żołnierzy i 35 oficerów (brak danych dotyczy bastionu V oraz kurtyny V-VI, stąd szacunkowo można przyjąć całkowitą liczbę załogi na ok. 2200 żołnierzy i 50 oficerów).

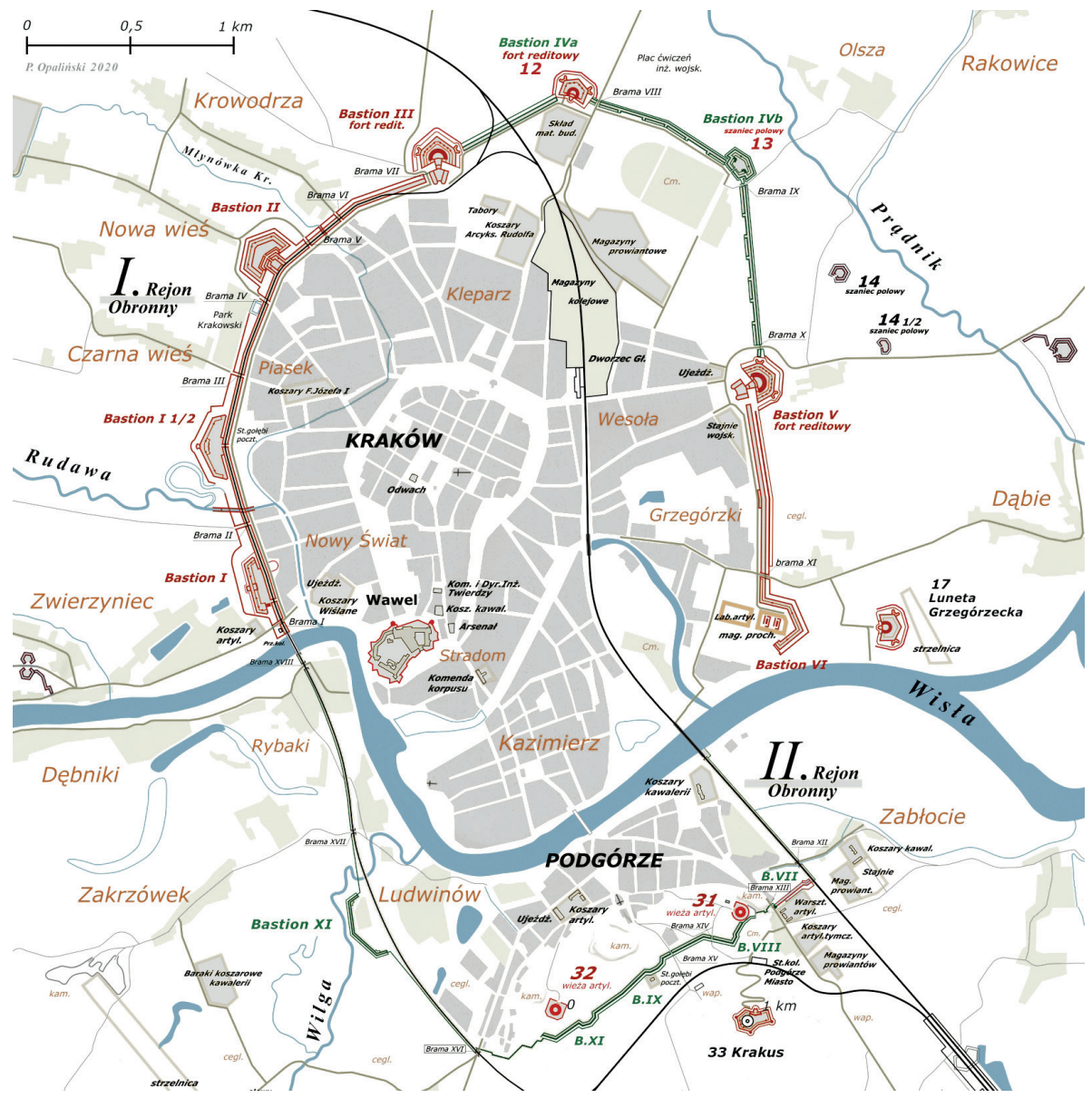

Ryc. 5. Rozbudowa Noyau na lewym i prawym brzegu Wisły - plan według stanu z $1888 \mathrm{r}$. (oprac. P. OPALIŃSKI)

48 J. PurChla, Matecznik polski. Pozaekonomiczne czynniki rozwoju Krakowa wokresie autonomii galicyjskiej, Kraków 1992, s. 104.

49 D. Lulewicz, Krakowskie drogi żelazne, Kraków 2019, s. 33. 
Noyau lewobrzeżne przewidywano uzbroić następująco ${ }^{50}$ :

- Bastion Iw 4 armaty (8 cm F.K. M.63) i 1 moździerz (15 cm);

- Bastion I 1 1/2 w 4 armaty (15 cm Schwere G.K.) i 2 moździerze $(17 \mathrm{~cm})$;

- Kurtyna I I $1 / 2$ - II w 4 moździerze $(24 \mathrm{~cm})$;

- Bastion II w 4 armaty (12 cm H.K. M.61) i 2 moździerze (17 cm);

- Bastion III w 4 armaty (12 cm H.K. M.61), 2 armaty (15 cm H.K. M.61), 8 armat (15 cm Leichte G.K.), 2 armaty (15 cm Schwere G.K.) i 2 moździerze $(17 \mathrm{~cm})$;

- Bastion IVa (12) podobnie jak bastion III;

- Kurtyna IVa-IVb w 4 moździerze $(24 \mathrm{~cm})$;

- Bastion IVb (13)w 4 armaty (12 cm H.K. M.61), 3 armaty (8 cm F.K. M.63) i 2 moździerze (17 cm);

- Bastion V podobnie jak bastion III;

- Kurtyna V-VI w 4 moździerze $(24 \mathrm{~cm}$ i $30 \mathrm{~cm})$;

- Bastion VIw 4 armaty (8 cm F.K. M.1863).

W 1888 r. ukończono Noyau podgórskie. Południowy front oparto o krzemionkowskie wieże artyleryjskie połączone linią wykutych w skale fortyfikacji bastionowych (o numerach od VIII do X). Skrzyd to wschodnie stanowił nasyp kolejowy wraz z półbastionem VII i murem przecinającym dawny kamieniołom przy wieży 31 . Zachodnie skrzydło rdzenia biegło w linii wału kolei cyrkumwalacyjnej osłoniętej rozległym ziemnym bastionem XI oraz poligonalnym murem opatrzonym strzelnicami u podnóży działobitni wieżowej 32. Przejazd w obwałowaniach zapewniały trzy bramy oraz dwie furty. Brama „Wielicka” zlokalizowana w pobliżu półbastionu VII otrzymała dodatkowo murowaną obronną wartownię̧51.

Dane dotyczące planowanego wyposażenia rdzenia podgórskiego w $1888 \mathrm{r}$. znane są jedynie w wypadku wież 31 i 32 . Obie miały posiadać takie same uzbrojenie, po dwie armaty $15 \mathrm{~cm}$ Leichte G.K.52 Późniejsze wykazy precyzują

${ }^{50}$ KA, KPS LB K VII h, 110 1/2, Adjustierte Spezialkarte mit Legende über die militärischen Bauobjekte, 1888.

51 CAW, DOK V, sygn. I.371.5.84, Ubersichts-Plan des Noyaus am rechten Weichselufer, K. u. k. Genie und Befestigungs Bau Direktion zu Krakau, 1894.

52 Ibidem. 
liczbę dział na sąsiednich umocnieniach. Po dwie sztuki armat polowych miały znaleźć się na bastionach VII i VIII oraz po cztery sztuki w bastionach IX, X i XI.

W latach1892-1893 rozszerzono obwód rdzenia prawobrzeżnego na tereny Dębnik, Zakrzówka, Ludwinowa i Zabłocia, odcinek biegnący grzbietem Krzemionek pozostał w niezmienionej formie. Umocnienia zaprojektowano pod nadzorem Dyrektora Inżynierii podporucznika Albina Kropscha ${ }^{53}$. Nowe cztery forty półstałe Stz. I-IV, o spłaszczonych stokach, połączone zostały prostymi odcinkami wałów poprzedzonych płytką fosą i pasem przeszkód drutowych.

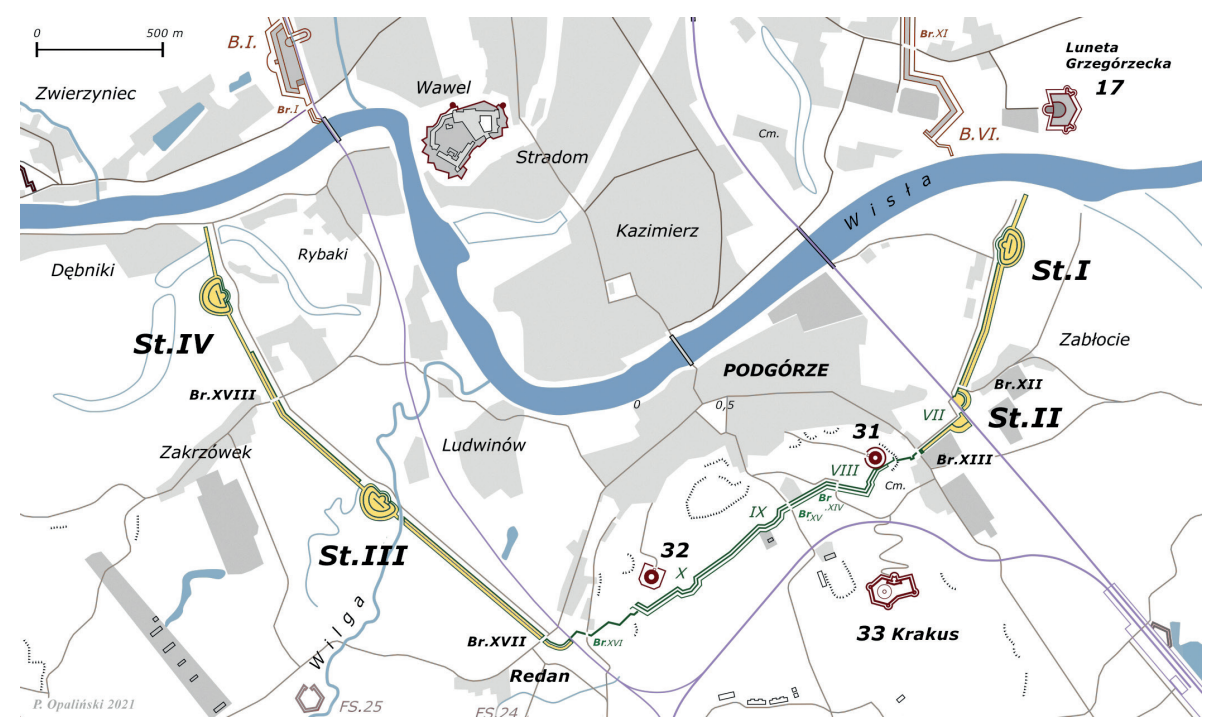

Ryc. 6. Poszerzenie rdzenia prawobrzeżnego (podgórskiego) - stan z 1893 r. (oprac. P. OPALIŃSKI)

Obsada mobilizacyjna każdego z fortów to średnio 50 artylerzystów, 30 żołnierzy piechoty i 6 saperów. Uzbrojenie stanowily armaty polowe $9 \mathrm{~cm}$ F.K. M.75 w liczbie od czterech do sześciu sztuk. W sumie cały południowy Noyau miał zostać uzbrojony w 26 dział, załoga miała liczyć 13 oficerów, dwa bataliony piechoty ${ }^{54}, 429$ artylerzystów i 18 pionierów ${ }^{55}$.

\footnotetext{
53 Schematismus für das k. u. k. Heer und für die k. u. k. Kriegs-Marine 1892, Wien 1892, s. 799.

${ }^{54}$ Baon przed pierwszą wojną światową liczył 4 kompanie po 200-250 żołnierzy.

${ }_{55}$ Schematismus für das k. u. k. Heer..., s. 799.
} 


\section{Obiekty pierwszego Noyau w topografii współczesnego Krakowa}

Kres istnienia umocnień rdzenia lewobrzeżnego nastąpił w 1908 r. Wzdłuż linii zachodnich wysuniętych szańców polowych rozpoczęto realizację drugiego, nowego Noyau ${ }^{56}$. Po roku 1911 przystąpiono do niwelacji obwałowań bastionów od I do II, umożliwiając ekspansję miasta na uwolnione z zakazu budowy atrakcyjne obszary. Niewielki północny fragment starego rdzenia włączono w linie nowych umocnien' ${ }^{57}$. Bastiony III i V miały odtąd pełnić funkcje koszarowe, a później magazynowe. Po wybuchu pierwszej wojny światowej na południowym brzegu Wisły również przesunięto główny ciężar wewnętrznej obrony z rdzenia na linię szańców przekształconych w punkty oporu. Sukcesywną rozbiórkę umocnień prawobrzeżnych prowadzono w czasie międzywojnia oraz w latach pięćdziesiątych XX w.

$\mathrm{Z}$ bogatego zespołu fortyfikacji Noyau do dziś zachowało się niewiele elementów. Z fortów detaszowanych przetrwały fort 2 „Kościuszko” oraz fort 7 „Za Rzeką”. Zdecydowanie lepiej wygląda zasób zachowanych dzieł pierścienia fortów artyleryjskich i pancernych zrealizowanych w latach 1881-1899.

Dawny układ umocnień Noyau został utrwalony w postaci przebiegu ulic i głównych szlaków komunikacyjnych dzisiejszego Krakowa. W linii współczesnych szerokich arterii takich jak Aleje Trzech Wieszczów, Beliny-Prażmowskiego czy Powstania Warszawskiego biegły drogi kryte, fosy, kurtyny oraz wewnętrzna rokadowa droga wałowa.

Bastion I „Nh. Zwierzyniec”8 ${ }^{2 n a j d o w a ł ~ s i e ̨ ~ p r z y ~ o b e c n e j ~ a l e i ~ K r a s i n ́ s k i e g o . ~}$ Płaskie czoło bastionu leżało równolegle do ul. Syrokomli, gdzie w centralnej części wschodniej pierzei kamienic znajdowała się osiowa kaponiera, a za nią wojenny magazyn amunicyjny. Prawy bark dotykał ul. Dunin-Wąsowicza, natomiast za lewym barkiem u wylotu obecnej ul. Morawskiego leżał skazamatowany schron flankujący wał biegnący w stronę brzegu wiślanego (rejon obecnego mostu Dębnickiego). Brama forteczna „Zwierzyniecka” znajdowała się na początku

56 CAW, DOK V, sygn. I.371.5.111, Noyau nördlich der Wichsel, K. u. k. Geniedirektion in Krakau, 1911.

57 Ibidem.

58 Około 1904 r. zmieniono oznaczenia istniejących obiektów fortyfikacyjnych z cyfr porządkowych na nazwy własne. Skrót Nh. z języka niemieckiego Noyaubauptwerk - dzieło główne rdzenia, Nz. to Noyauzwichenwerk - dzieło pośrednie rdzenia. 
ulicy Kościuszki. Natomiast brama „Wolska” na wysokości dzisiejszego hotelu Cracovia przy Piłsudskiego. Dalej ku północy szeroka fosa zajmowała obszar, na którym dziś znajduje się Muzeum Narodowe. Przed elewacją wejściową gmachu znajdował się początek wielkiej śluzy kontrolującej poziom wody płynącej korytem Rudawy od strony Błoń.

Bastion I 1/2 „Nh. Czysta” usytuowany był przy alei Mickiewicza u wylotu ulicy Krupniczej. Barki bastionu rozpościerały się między obecną Biblioteką Jagiellońską a głównym budynkiem Akademii Górniczo-Hutniczej. Kaponiera czołowa i magazyn amunicyjny znajdowały się między dzisiejszą fontanną a fasadą Uniwersytetu Rolniczego. Kurtyna biegnąca dalej w kierunku północnym posiadała bramę "Czarnowiejską" w osi ulicy o tej samej nazwie. Śladem po fosie i pasie wykupionego przez wojsko terenu jest Park Krakowski utworzony w 1885 r. jako jeden z pierwszych ogólnodostępnych terenów rekreacyjnych.

Ziemny bastion II „Nh. Karmelicka” znajdował się na styku alei Mickiewicza i Słowackiego. Przebieg obwałowań wytyczają ulica Pomorska i plac Inwalidów (lewe czoło i bark) oraz północno-zachodni narożnik placu Axentowicza (styk prawego czoła i barku). Czoło szyjowego śródszańca wskazuje wschodnia pierzeja ulicy Sienkiewicza. Dwie bramy znajdowały się w pobliżu bastionu - początkowo tylko jedna furta „Łobzowska”, a po 1888 r. kolejna „Karmelicka”. Z kolei 90 metrów na północ od bramy „Łobzowskiej” w rejonie dzisiejszej siedziby Radia Kraków znajdowała się śluza kontrolująca przepływ Młynówki Królewskiej.

Na końcu alei Słowackiego między ul. Kamienną i Prądnicką znajduje się dobrze zachowany do dziś, potężny ceglany fort-bastion III „Nh. Długa”. Na stokach dawnego glacis utworzono park miejski, natomiast w adaptowanych kazamatach fortecznych mieszczą się siedziby firm usługowych oraz lokale rozrywkowe.

Kolejny ziemny bastion IV znajdował się przed południowym murem cmentarza Rakowickiego. Po 11 latach od ukończenia budowy wraz z sąsiednimi kurtynami został skasowany, a otaczający teren stopniowo zajmowały magazyny i baraki zaplecza aprowizacyjnego. Jedynym punktem odniesienia szczęśliwie zachowanym jest neogotycka piekarnia wojskowa, usy tuowana na majdanie nieistniejącego bastionu. Po bramach „Warszawskiej” i „Olsza” również nie pozostał żaden ślad. Jedynie dwie rogatki akcyzowe przy alei 29 Listopada i ul. Rakowickiej sugerują obecność przejazdów w umocnieniach dawnego Noyau. Zmodyfikowane w latach osiemdziesiątych XIX w. wały podążały ul. Kamienną do nadal istniejącego fortu 12 (IVa) „Nh. Luneta Warszawska”. Dalej kurtyny 
i rowy przeszkodowe biegły terenem zajętym obecnie przez cmentarz, w stronę zmodernizowanego szańca 13 (IVb) „Nz. Rakowicka”, w którego miejscu wzniesiono biurowiec firmy telekomunikacyjnej. Stąd aleją Beliny-Prażmowskiego wał kierował się do drugiego w pełni murowanego dzieła obronnego. Bastion $\mathrm{V}$ „Nh. Lubicz” niestety nie doczekał naszych czasów, zniwelowany pod budowę węzła komunikacyjnego.

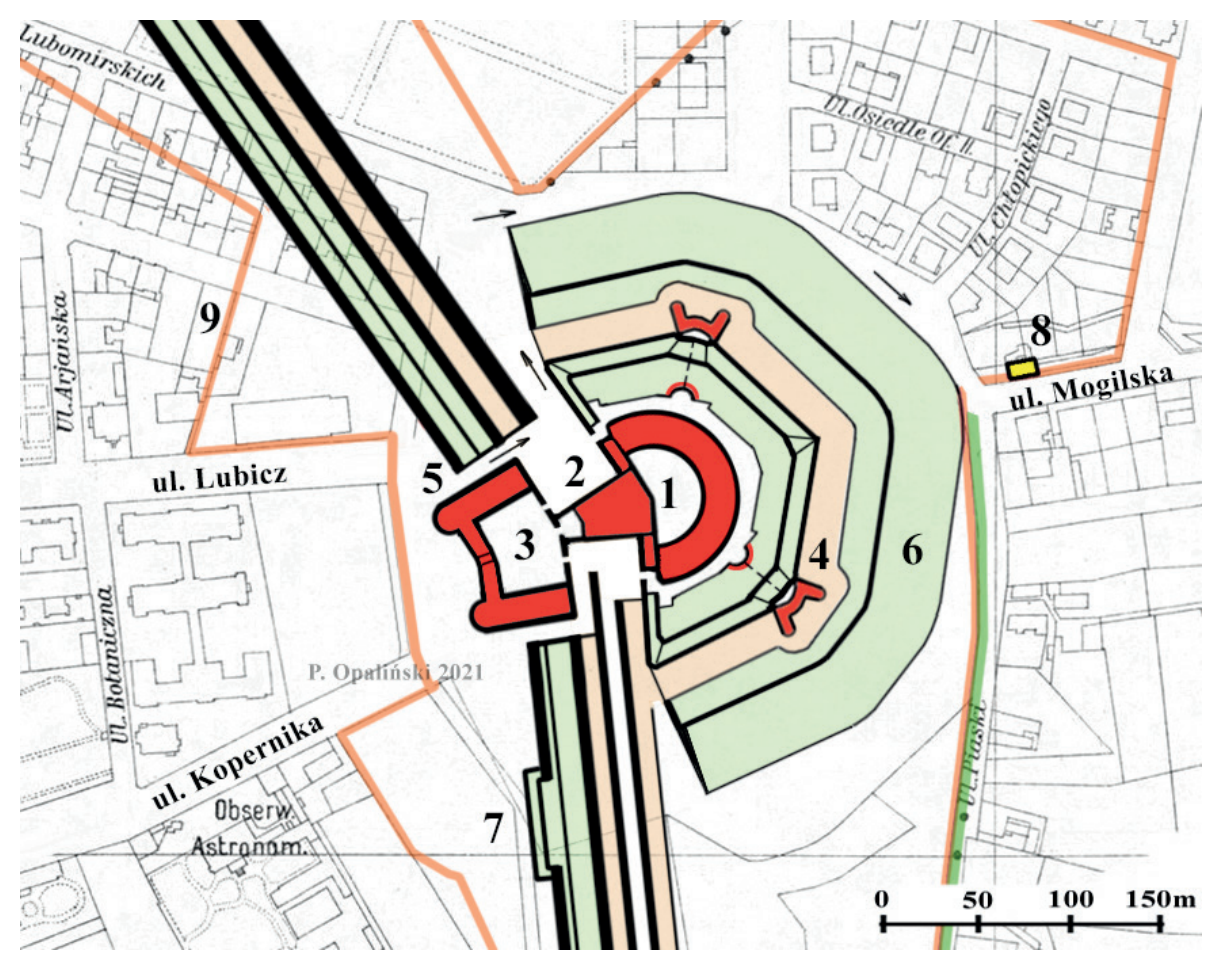

Ryc. 7. Rzut bastionu $V$ oraz sąsiednich kurtyn według stanu z lat 1866-1887, podkład geodezyjny z 1936 r. Legenda: 1 - redita, 2 - szyjowe kazamaty flankujące, 3 - podwójna kaponiera szyjowa z wewnętrznym dziedzińcem, 4 - kaponiera broniąca fosy, 5 - położenie bramy fortecznej, 6 - równia ogniowa (glacis) przed drogą krytą, 7 - bateria skrzydłowa w linii kurtyny, 8 - rogatka akcyzowa, 9 - granice działek fortecznych (oprac. P. OpALIŃSKI)

Obecnie na terenie Ronda Mogilskiego odsłonięto i wyeksponowano zachowane relikty kaponier i czoła fortu. Świadectwem obecności wałów frontu zachodniego jest przebieg alei Powstania Warszawskiego. Brama „Grzegórzki” była zlokalizowana przy południowej krawędzi Ronda Grzegórzeckiego.

Po wschodniej stronie ul. Kotlarskiej znajdował się ostatni obiekt rdzenia lewobrzeżnego, bastion VI „Laboratorium”. Przez długie lata lewe czoło dzieła 
wskazywało położenie jednej z hal fabryki maszyn Zieleniewskiego. Kilka lat temu wyburzono halę, przygotowując plac pod budowę nowoczesnego osiedla mieszkaniowego. Jedynym zachowanym reliktem związanym z tym bastionem jest pozbawiony nasypu ziemnego kamienny wojenny schron amunicyjny, leżący przy samej ul. Kotlarskiej na przedłużeniu osi ul. Semperitowców.

$\mathrm{Na}$ drugim brzegu Wisły o dawnym usytuowaniu wałów Noyau świadczy przebieg ul. Romanowicza na Zabłociu, a następnie Tarnowskiego, Radosnej i częściowo Krzemionki, po przeciwległej zaś stronie Podgórza ciąg ul. Komandosów oraz Szwedzkiej na Dębnikach. Z obiektów fortyfikacyjnych ocalały ceglana wieża artyleryjska 31 „św. Benedykt” oraz relikty wałów i fos ukrytych pośród zieleni pokrywającej wapienne stoki Krzemionek. W sąsiedztwie osiedla Podwawelskiego przetrwały relikty fortu Stz. III oraz przy skrzyżowaniu ul. Twardowskiego i Szwedzkiej obronna rogatka akcyzowa „Zakrzowiecka”.

\section{BIBLIOGRAFIA}

\section{Źródła archiwalne}

Archiwum Narodowe w Krakowie. Zbiór kartograficzny.

Centralne Archiwum Wojskowe, Wojskowe Biuro Historyczne w Warszawie

Dowództwo Okręgu Korpusu V.

Kriegsarchiv Wien

zbiory: Feldakten oraz Karten und Plansammlung.

\section{Prasa}

„Gazeta Warszawska” 1849.

\section{Opracowania}

Baczkowski M., Austriackie fortyfikacje w zachodniej Galicji w drugiejpotowie XVIII wieku, „Studia Historyczne” 1998, z. 1. 
Baczkowski M., Galicja a wojsko austriackie 1772-1867, Kraków 2017.

Benoit C., Fortyfikacja stata podczas wojny, Warszawa 1924.

Biesiadka J., Gawlak A., Kucharski S., Wojciechowski M., Twierdza Poznań. O fortyfikacjach miasta Poznania w XIX i XX wieku, Poznań 2006.

Bogdanowski J., Architektura obronna w krajobrazie Polski, Warszawa 2002.

Bogdanowski J., Fortyfikacje austriackie na terenie Galicji w latach 1850-1914, Kraków 1993.

Bogdanowski J., Warownie i zieleń Twierdzy Kraków, Kraków 1979.

Forstner F., Twierdza Przemyśl, Warszawa 2000.

Gollenhofer J., Rewolucya krakowska 1848 roku, Kraków 1908.

Hillbrand E., Turme von Linz, [w:] Historisches Jabrbuch der Stadt Linz, Archiv der Stadt Linz 1985, R. 1984.

Lulewicz D., Krakowskie drogi żelazne, Kraków 2019.

Lulewicz D., O kolei i mostach w Podgórzu, [w:] Dwa miasta, dwa brzegi w 100. rocznice potączenia Podgórza i Krakowa (1915-2015), red. E. Firlet, Kraków 2015, s. 219-275.

Mikulski M., Kilka stów o kosztach budowy Twierdzy Kraków, „Cztery Historie” 2011, t. 1.

Mikulski M., Środulska-Wielgus J., Wielgus K., Pstuś D., Obronność Krakowa w XIX iXX wieku jako element rozwoju miasta, [w:] Kraków. Nowe studia nad rozwojem miasta, red. J. Wyrozumski, Kraków 2007.

Oprzysztość Twierdzy Kraków. Opracowanie studialne dla planu ochrony zespotu historyczno-krajobrazowego Twierdzy Kraków, red. H. Rojkowska-Tasak, M. Szkoła, K. Wielgus, K. Chajdys, „Atlas Twierdzy Kraków” 2010, Seria II, t. 5.

Opaliński P., Austriackie fortyfikacje Podgórza w latach 1790-1859, [w:] Miasto pod kopcem Kraka, red. E. Firlet, Kraków 2016, s. 199-244.

Österreichisches Biographisches Lexikon 1815-1950, Österreichische Akademie der Wissenschaften, Wien 1983.

Österreichischer Militär-Schematismus, k. k. Hof- und Staatsdruckerey, Wien 1815-1918.

Purchla J., Matecznik polski. Pozaekonomiczne czynniki rozwoju Krakowa w okresie autonomii galicyjskiej, Kraków 1992.

Tobiasz M., Dziejowe przemiany sieci wodnej i zagospodarowania przestrzennego Krakowa, Państwowa Akademia Nauk, Kraków 1977.

Witold-Aleksandrowicz A., Rozwój historyczny fortyfikacji, Toruń 1924.

Wurzbach C., Biographische Lexikon des Kaiserthums Öesterreich, Wien 1856-1891.

\section{Netografia}

https://mapire.eu/en/map/secondsurvey-galicia (dostęp: 9 I 2021). 


\section{Piotr Opaliński}

\section{NOYAU OF THE KRAKOW FORTRESS IN THE SECOND HALF OF THE 19TH CENTURY}

Summary. In 1857 the Austrian military authorities started building an internal line of defence in the Krakow fortress, known as Noyau. Krakow, as an extremely important strategic point on the map of the Habsburg monarchy, required urgent fortification. The works were preceded by field studies and considerations of several variants of the planned fortifications. In progress, obstacles appeared which caused completion of the investment only after 9 years. The construction of Noyau, permanently saved in the history of the city, affected its urban planning and spatial development. Despite the demolition of most of the fortifications, we can still see a trace of their presence in the form of a system of communication routes, surrounding today's downtown of Krakow.

Keywords: fortification, fortress Krakow, Noyau, city defence, Cornelius von Wurmb 